\title{
İlköğretim Öğrencilerinin Din Öğretimi Sürecinde İlgi Duydukları Konular (Ankara İli Örneğinde 6, 7 ve 8. Sınıf Öğrencileri Üzerinde Karşılaştırmalı Bir Analiz)
}

\author{
NURULLAH ALTAS \\ DOÇ. DR., ANKARA Ü. İLAHIYAT FAKÜLTESI \\ e-posta: altas@divinity.ankara.edu.tr
}

\begin{abstract}
Subjects Which are Primary Students Interested in the Process of Taking Religious Education. Who aTeaching programs can not disregard the students' interests and needs. Therefore, while developing the programs of Religious Culture and Ethics, the studies done on the matters the students show interest in have been made use of. Given the fact that the program developing is a process, it is obvious that the teaching programs should continuously be revised in line with the new scientific findings. This research aims to identify in which the classes and what matters do the students show more interest in the process of teaching conducted on the basis of the of primary school teaching program of Religious Culture and Ethics course that took affect in 2007. To that end, the data obtained from the students have been analyzed in accordance with the classes, and the findings being interpreted. In the conclusion part of research, suggestions have been given place.
\end{abstract}

key words

Religious education, education, religion, education in Turkey

\section{A. GiRiş}

Öğretim programlarının geliştirilmesinde öğrenenlerin ilgi ve ihtiyaçlarını belirlemek önemli bir aşama olarak kabul edilir. Öğrenen merkezli bir öğretim anlayışında öğrenenin ilgi ve ihtiyaçları, öğretim programının amaçlarının belirlenmesinde, öğretimin içeriğini düzenlemeye ve öğretim sürecini yapılandırmada merkezde yer alan bir faktördür. Öğrenenin merkezde yer 
alması, ülkemiz program geliştirme çalışmalarında da son on yıllarda giderek daha fazla dikkat edilen bir ilke olarak gözümüze çarpmaktadır. Nitekim 2000 ve 2005 yıllarında ilköğretim din kültürü ve ahlak bilgisi programlarında gerçekleştirilen geliştirme çalışmalarında bu vurgu her fırsatta karş1mıza çıkmaktadır.

1982 yılında yayınlanan "Din Kültürü ve Ahlak Bilgisi Derslerinin Temel İlkeleri", konuların öğrencilerin genel kültür ve pedagojik gelişmeleri göz önünde bulundurulmak suretiyle, onların kültür düzeylerini aşmadan işlenmesini öngörmektedir. 2000-2001 Öğretim yılından itibaren ilköğretim okullarında uygulanmaya başlanan Din Kültürü ve Ahlak Bilgisi öğretim programlarının en önemli özelliği, geliştirme sürecine rehberlik eden ilkelerdir. Bu temel ilkeler üç grup altında sıralanmıştır. Bunlardan birinci grupta yer alan ilkelerde demokratik, laik ve sosyal hukuk devleti olan Türkiye'de bireylerde bulunması gereken çağdaş eğitimsel özellikler yer almaktadır. Bu özellikler şu şekilde sıralanmıştır: Eğitimsel süreçlerde aktif olarak yer alan, bu süreçlerde kazanılan yeterlilikleri yaşamına taşıyabilen, bilimsel verileri dikkate alan, "Öğrenmeyi öğrenme" yeterliliğini kazanan ve yaşam boyu öğrenmeyi alışkanlık haline getiren, araştıran, soran, sorgulayan, demokrasiyi özümsemiş, hoşgörülü bireyler yetiştirilmesidir. Bu ilkeler, programlarda öğrenenin merkeze alındığını gösteren ölçütlerdir.

2007 yılında yayınlanan ve 2007-2008 öğretim yılında uygulamaya geçirilen İlköğretim Din Kültürü ve Ahlak Bilgisi Öğretim Programları öncekilerden farklı bir anlayışla hazırlanmıştır Bu programların giriş bölümünde öncelikle öğrencilerin din ve ahlak hakkında objektif bilgi sahibi olmaları, öğrenme-öğretme sürecinde öğretim programı vasıtasıyla kazanmaları hedeflenen bilgi, beceri, tutum, değer, kavram ve öğrenci merkezli yaklaşımlarla bir arada yaşama bilincine ulaşmalarının hedeflendiği vurgulanmaktadır. Bu programlarda yapılandırmacı yaklaşım, çoklu zekâ, öğrenci merkezli öğrenme gibi yaklaşımlar dikkate alınmışırı. Yapılandırmacı yaklaşıma göre öğrenme sürecinde ön bilgileri harekete geçirme, gelişim düzeyini dikkate alma, etkili iletişim kurma, anlam kurma, uygulama ve değerlendirme önemli kavramlardır. Öğrenen merkezli eğitimi temel alan yapılandırmacı yaklaşım, öğrenme sürecinde öğrenci katılımına ve öğretmen rehberliğine ağırlık vermektedir. Programlardaki bu ifadeler, öğretim programının tüm süreçlerinde öğrenenin ilgilerinin ve ihtiyaçlarının merkeze alındığını ortaya koymaktadır.

Biz bu araştırmada, öğretim programlarında kullanılan içeriğin öğrencilerden toplanan veriler yardımı ile ilgi ve ihtiyaçları hangi ölçüde karşıladığını ve öğrenen beklentilerinin neler olduğunu ortaya koymaya çalıştık. Prog- 
ram geliştirmenin bir süreç olduğundan hareketle öğrencilerden elde edilen veriler yardımı ile hangi düzeltmelerin yapılması gerektiği noktasında ise öneriler geliştirdik. Bu çerçevede araştırmamız, öğrencilerin programlarda kullanılan içeriğe yönelik değerlendirme ve beklentilerini ortaya koyan bulguların yorumlanması ve bu yorumlara dayalı olarak geliştirilen önerilerden oluşmaktadır.

\section{B. YÖNTEM}

İlköğretim öğrencilerinin uygulanmakta olan din kültürü ve ahlak bilgisi öğretim programlarına yönelik düşüncelerine dayalı bulgulardan hareket ederek onların din öğretimi konusundaki ilgi ve ihtiyaçlarını belirleme üzerine kurulu araştırmamız iki aşamada gerçekleştirilmiştir. Birinci aşamada nitel yöntem tercih edilmiştir. Bu alanda yapılan araştırmalarda genellikle yapılandırılmış formlar aracılığı ile bilgi toplanmakta, problemler belirlenmekte ancak bulgular, kullanılan ölçme araçlarının birbirlerini tekrarlaması nedeniyle hep benzer problem boyutuna odaklanmaktadır. Bu nedenle araştırmamızda yarı yapılandırılmış bir ölçme aracı kullanılmıştır. Bu araçta ilköğretim öğrencilerinden, almış oldukları Din Kültürü ve Ahlak Bilgisi dersleri kapsamında ilgilendikleri konular, ilgisiz oldukları konular, programlara alınmasını istedikleri konular ve dinle ilgili sıklıkla sormuş oldukları soruları, önemli gördüklerinden başlayarak beş madde halinde yazmaları istenmiştir.

İkinci aşamada ise açı uçlu olarak alınan bu bulgular SPSS veri analiz programına girilmiş, önem sırasına göre 1 . sırada yer alan madde 5 , son sırada yazılan madde ise 1 puanla puanlandırılmıştır. Böylece her bir madde için, araştırmaya katılan tüm deneklerden toplam ve ortalama puanları alma imkânı elde edilmiştir. Daha sonra elde edilen veriler ilgili oldukları konulara göre gruplandırılmış ve bu gruplara göre yeni değişkenler elde edilmiştir. Araştırmamız elde edilen bu bulgulardan "Öğrencilerin ilgilendikleri konular" üzerine odaklanmaktadır. Bu başlık altında gruplandırılan konulara ait ortalama puanların öğrencinin okuduğu sınıfa göre istatistiksel açıdan anlamlı bir farklılaşma gösterip göstermediği tek faktörlü varyans analizine (ANOVA) tabi tutulmuş ve anlamlı farklılaşma gösteren konu grupları, ilgili öğrenme alanı temel başlığı altında çözümlenerek yorumlar geliştirilmiştir.

Araştırma, Ankara örneği üzerinde atama yöntemiyle belirlenen 7 ilköğretim okulunda 481 öğrenciden elde edilen bulgular yardımı ile gerçekleştirilmiştir. İlköğretim aşamasında din kültürü ve ahlak bilgisi öğretimi 4. sınıftan 8. sınıfa kadar haftada iki saat olarak uygulanmaktadır. Bununla birlikte 4. ve 5. sinıf öğrencileri üzerinde yapılan uygulamada öğrencilerin kitaplara bağlı bilgi vermeye eğilimli oldukları gözlendiğinden 
araştırmanın güvenilirliğini yükseltmek amacıyla bu sınıflar kapsam dışında bırakılmıştır. Araştırma bulguları 6, 7 ve 8. sınıf öğrencilerinden elde edilen bulgularla sinırlıdir.

Örneklem atama yoluyla belirlenmiştir. Atamada, Ankara Üniversitesi İlahiyat Fakültesi İlköğretim Din Kültürü ve Ahlak Bilgisi Öğretmenliği Bölümü öğrencilerinin aldığı Okul Deneyimi dersi etkinlikleri için belirlenen okullar dikkate alınmıştır. Atanan bu okullar Ankara'nın sosyo-ekonomik açıdan farklı semtlerini temsil ettikleri varsayılmaktadır.

\section{DIN KÜLTÜRÜ VE AHLAK BILGISI ÖĞRETIMINDE ÖĞRENCILERIN ILGILENDIĞI KONULAR}

Öğrencilerin İlköğretim Din Kültürü ve Ahlak Bilgisi öğretim programlarında en fazla ilgi duydukları, beğendikleri ve sevdikleri konuların sıralamasından elde edilen ortalama puanlara göre dizini tablo 1'de verilmektedir. Tablo incelendiği zaman Hz. Peygamber'in hayatı ve öğretileri ile ilgili konuların ilk sırada yer aldığı görülmektedir. Bunu sırası ile İslam, İslam'ın şartları ve ibadetler ve ahlak, İslam ahlakı, ahlaki görevlerimizle ilgili konular izlemektedir. Öğrencilerin ilgilendiklerini söyledikleri konularda en az ortalama ile alt sıralarda ise dinin toplumsal boyutu, din-devlet ilişkileri, laiklik ve dinen yasaklanan ve izin verilen hususlara vurgu yapan konular yer almaktadır.

Tablo 1: Öğrencilerin Programlarda İlgi Duydukları Konular

\begin{tabular}{lc} 
& Ortalama \\
\hline Hz. Muhammed'in Hayatı ve Öğretileri & 2,3181 \\
İslam/İslam'ın Şartları/İbadet Konuları & 1,4513 \\
Ahlak/İslam Ahlakı/Ahlaki Görevlerimiz & 0,9324 \\
Diğer Dinlerin Kitapları & 0,9105 \\
Melekler ve Meleklere İman & 0,7972 \\
Cin/Ruh/Peri/Şeytan & 0,7833 \\
Ahiret/Ölümden Sonraki Hayat & 0,7177 \\
Namaz & 0,6978 \\
Diğer Peygamberlerin Hayatları ve Öğretileri & 0,5328 \\
Din Kurumu/ İhtiyaçları ve Özellikleri & 0,493 \\
Kuran-ı Kerim/Öğretileri/Öğretimi & 0,493 \\
Allah Düsüncesi/Allah'a İman & 0,4623 \\
Sihir ve Büyü & 0,2684 \\
İslam'da İman ve İman Edilecek Konular & 0,2167 \\
Mucize/Olağanüstü Olaylar/Keramet/Yaşanmış Dini Hikayeler & 0,2127 \\
Aile/Anne/Baba Hakları & 0,1909 \\
Kaza-Kader İnancı & 0,1829 \\
Evren/Dünya ve Yaratılışları & 0,1412 \\
İslam Tarihi/Coğrafyası/Kültür ve Uygarlığı & 0,1193
\end{tabular}


Diğer Dinler ve Özellikleri Hakkında Bilgi $\quad 0,0855$

Kiyamet ve Alametleri $\quad 0,0278$

Dinin Toplumsal Boyutu/Devletle İlişkileri/Laiklik $\quad 0,0258$

İslam'da Helal ve Haramlar $\quad 0,0179$

\section{1. İnanç Öğrenme Alanında Bulunan Konuların Sınıflara Göre Farklılaşması}

Öğrencilerin ilgilendikleri "İman Öğrenme Alanı"nda yer alan konuların sınıflara göre dağılımının istatistiksel açıdan farklılaşmasını belirlemek amacıyla tek faktörlü varyans analizi (Anova) yapılmıştır. Analiz sonuçlarına göre konulara ait ortalama puanlardan sınıflara göre anlamlı bir şekilde farklılaşanları tablo 2'de sunulmuştur.

Allah düşüncesi ve Allah'a imanla ilgili öğrencilerin ilgilendikleri konulara ait ortalama puan genelde diğer konulara göre düşük bir ortalamaya sahiptir $(0,46)$. Sinıflara ait ortalamaya baktığımızda 6 . sınıfta en düşük oran iken bu, 7. sınıfta yükselmekte ve 8 . sınıfta tekrar düşmekle birlikte yine de 6. sınıfın oldukça üstünde bir değer olarak karşımıza çıkmaktadır. Allah düşüncesi ve Allah'a iman konuları inanç öğrenme alanında bulunan 4. sınıftaki "Din ve Ahlak Hakkında Neler Biliyoruz" ve 5. sınıftaki "Allah İnancı" üniteleri içinde yer almaktadır. Öğrenci bu konuları doğrudan 6,7 ve 8. sınıfta bir daha görmemektedir. Bu konular 1982 programında 4, 5, 6 ve 7. sinıflarda konunun farklı boyutlarını içerecek şekilde tekrarlayarak yer almaktaydı. Ancak 2000 programlarında bu konu sadece 5. sınıftaki ünite ile sınırlı tutulmuş, 2007 programları da aynı yolu izlemiştir. Konunun sadece bir sınıfta işleniyor olması, soyut ve kuramsal bilgileri içermesi, diğer derslerle ilişkilendirmeye uygun bir konu olmaması öğrencilerin ilgi alanında alt sıralarda yer almasını beraberinde getirmiştir. Bu konulara ilgi düzeyi, 6. sınıflarda düşük görünmektedir. İlköğretim programını 4-8. sinıflar arasında bir bütün olarak düşündüğümüzde Allah düşüncesi ve Allah inancı ile ilgili konuların 4. sınıftan itibaren somut yansımaları ile (kültüre ve dile) gittikçe soyutlaşarak yer alması gerekmektedir.

Tablo 2: İnanç Öğrenme Alanında Yer Alan Konuların Sınıflara Göre Dağılımı

\begin{tabular}{llrrr} 
& & N & \multicolumn{1}{c}{ Ort. } & \multicolumn{1}{c}{ ss } \\
\hline Allah Düşüncesi/ & & & & \\
Allah'a İman & İlköğretim 6.sinıf & 199 & 0,191 & 0,90661 \\
& İlköğretim 7. sinıf & 191 & 0,644 & 1,58245 \\
& İlköğretim 8. sinıf & 92 & 0,3913 & 1,23996 \\
& Toplam & 481 & 0,4623 & 1,3371
\end{tabular}




\begin{tabular}{|c|c|c|c|c|}
\hline \multicolumn{5}{|l|}{ Ahiret/Ölümden } \\
\hline \multirow[t]{4}{*}{ Sonraki Hayat } & İlköğretim 6.sınıf & 199 & 0,1508 & 0,72292 \\
\hline & İlköğretim 7. sınıf & 191 & 1,5236 & 1,91345 \\
\hline & İlköğretim 8. sınıf & 91 & 0,4396 & 1,24908 \\
\hline & Toplam & 481 & 0,7177 & 1,51086 \\
\hline \multicolumn{5}{|l|}{ Evren/Dünya ve } \\
\hline \multirow[t]{4}{*}{ Yaratılışları } & İlköğretim 6.sınıf & 199 & 0,0251 & 0,35444 \\
\hline & İlköğretim 7. sınıf & 191 & 0,2461 & 0,93874 \\
\hline & İlköğretim 8. sınıf & 91 & 0,1319 & 0,73347 \\
\hline & Toplam & 481 & 0,1412 & 0,72102 \\
\hline \multicolumn{5}{|l|}{ İmanla İlgili Diğer } \\
\hline \multirow[t]{4}{*}{ Konular } & İlköğretim 6.sınıf & 199 & 0 & 0 \\
\hline & İlköğretim 7. sınıf & 191 & 0,0471 & 0,46212 \\
\hline & İlköğretim 8. sınıf & 91 & 1,0989 & 1,81387 \\
\hline & Toplam & 481 & 0,2167 & 0,91836 \\
\hline \multirow[t]{4}{*}{ Kaza-Kader İnancı } & İlköğretim 6.sınıf & 199 & 0 & 0 \\
\hline & İlköğretim 7. sınıf & 191 & 0,0733 & 0,52802 \\
\hline & İlköğretim 8. sınıf & 91 & 0,8571 & 1,62324 \\
\hline & Toplam & 481 & 0,1829 & 0,8244 \\
\hline \multicolumn{5}{|l|}{ Melekler ve } \\
\hline \multirow[t]{4}{*}{ Meleklere İman } & İlköğretim 6.sınıf & 199 & 0,206 & 0,90048 \\
\hline & İlköğretim 7. sınıf & 191 & 1,7539 & 1,96205 \\
\hline & İlköğretim 8. sınıf & 91 & 0,2527 & 0,92608 \\
\hline & Toplam & 481 & 0,7972 & 1,58008 \\
\hline \multicolumn{5}{|l|}{ Diğer Görünmeyen } \\
\hline \multirow[t]{6}{*}{ Varlıklar } & İlköğretim 6.sınıf & 199 & 0,1407 & 0,70374 \\
\hline & İlköğretim 7. sınıf & 191 & 1,8848 & 2,01242 \\
\hline & İlköğretim 8. sınıf & 91 & 0,0659 & 0,44227 \\
\hline & Toplam & 481 & 0,7833 & 1,5839 \\
\hline & İlköğretim 7. sınıf & 191 & 0,3613 & 1,16545 \\
\hline & İlköğretim 8. sınıf & 91 & 0 & 0 \\
\hline \multicolumn{5}{|l|}{ Kiyamet ve } \\
\hline \multirow[t]{4}{*}{ Alametleri } & İlköğretim 6.sınıf & 199 & 0 & 0 \\
\hline & İlköğretim 7. sınıf & 191 & 0,0209 & 0,22845 \\
\hline & İlköğretim 8. sınıf & 91 & 0,1099 & 0,73712 \\
\hline & Toplam & 481 & 0,0278 & 0,34459 \\
\hline
\end{tabular}

"Melek ve Ahiret İnancı" isimli ünite, öğretim programlarında 7. sınıf 1. ünite olarak yer almaktadır. Öğrencilerin ilgilendiklerini söyledikleri konuların bir kısmı Ahiret ve ölümden sonraki hayatla ilgili bulunmuş ve bu başlık altında toplanmıştır. Kıyamet, ölümden sonraki yaşam, cennet, cehen- 
nem, hesap, sırat köprüsü vb. konular bu başlık altına alınmıştır. İlgi düzeyi açısından tüm öğrenciler içinde yapılan değerlendirmede üst grup içinde yer alan bir konu olarak karşımıza çıkmaktadır. Sınıflara göre farklılaşma anlamlıdır. Altıncı sınıflarda oldukça düşük bir ortalama gözlenirken 7. s1nıflarda yükselmekte ve 8 . sınıflarda tekrar düşmektedir. Bununla birlikte 8 . sinıflarda ilgi düzeyi 6. sinıflara göre yüksektir.

Evrenin yoktan var edilmesi, ilk yaratılış, öğretim programlarında 5. sınıf birinci ünite "Allah İnancı" ve 8. sınıf birinci ünite "Kaza ve Kader"'de konu edilmektedir ve ünite açılımları öğrencinin ilk yaratılışla ilgili sorunlarını tartışmaya yeterli değildir. Halbuki öğrencilerin ilgi duydukları konuların bir kısmı evrenin ilk oluşumu ve ilk yaratılışla ilgilidir. "Nereden Geliyoruz" sorusu insanoğlunun temel varlık sorularından birisidir ve öğretim sürecinin herhangi bir aşamasında bu sorunun ortaya çıkması kaçınılmazdır. Din Kültürü ve Ahlak ilgisi dersleri de bu sorunun ortaya çıkmasında tetikleyici bir faktördür. Sınıflara göre ilgi düzeyleri incelendiği zaman 6. sınıfta oldukça düşük olan ilgi düzeyi 7. sınıfta yükselmekte ve 8. sınıfta tekrar düşmektedir. Sekizinci sınıftaki ilgi düzeyi 6. sınıfa göre düşüktür. Bu konu ile ilgili öğretimin 5. sınıfta yapıldığı göz önüne alındığında ilginin 7. sınıfta diğer sınıflara göre yüksek çıkması üzerinde düşünülmesi gereken bir konudur.

İnsanların başlarına gelen olayları hangi oranda kontrol edebilecekleri, peygamberliğin günümüz insanı için model oluşturup oluşturamayacă̆ı, meleklerin gücünün gözlenmesi ve dinin bu devirde mutluluk sağlayıp sağlayamayacağı gibi tartışma içeren üst düzey konular "imanla ilgili diğer konular" başlığı altında değerlendirilmiştir. İnanç bağlamında bu tür konular sınıf ortamında öğretim programında yer alamasa dahi tartışma konusu yapılmaktadır. Nitekim öğrencilerden alınan bilgiler, bu konuların ilgi odağı olduğunu göstermektedir. Sınıflara göre farklılaşmaya bakıldığı zaman bu konuların 6. sınıflarda hiç bulunmadığı halde çok düşük bir ortalama ile 7. sinıflarda ortaya çıktığını ve 8. sinıflarda en üst düzeyde bulunduğunu göstermektedir.

"Kaza ve Kader" inancı programda 8. sınıf 1 . ünite olarak yer almaktadır ve öğrencilerin ilgi duydukları konuların "Kaza ve Kader" konusu ile ilgili olanların ortalama puanları 6 ve 7. sınıfta yükselerek 8. sınıfta en üst düzeye ulaşmaktadır. Bu bulgular bize programdaki yerleştirme ile öğrenci ilgilerinin paralel olduğunu göstermektedir.

"Melekler ve Meleklere İman" başlı̆̆ı altında toplanan konuların 6 ve 8 . sınıfta bir birine yakın ortalamalar ile 7. sınıftaki ortalamanın altında olduğu görülmektedir. Melek inancı, 7. sınıf 1. ünitede işlenmektedir ve elde ettiğimiz bulgular, bu yerleşimin doğru olduğunu göstermektedir. 
Öğrencilerden alınan bilgiler ilgi duyulan konuların bir kısmının cin, ruh, peri ve şeytan gibi görünmeyen diğer varlıklarla ilgili olduğunu göstermektedir. Bu konulara duyulan ilgi, ilköğretim 6. sınıf ve 8. sinıfta birbirine yakın ortalama ile 7. sınıfın oldukça gerisindedir. Görünmeyen varlıklar konusu, uygulanan öğretim programında 7. sınıf 1 . ünitede yer almaktadır ve elde ettiğimiz bulgular çerçevesinde düşünüldüğg̈nnde uygun görünmektedir.

Kıymet alametleri ile ilgili sorular ayrı bir grup altında toplanmıştır. Aslında bu konu ahiretle de ilgili olsa sahip olduğu ortalama itibarı ile ayrı bir grup olarak değerlendirilmiştir. İlginç bir şekilde ahiretle ilgili konulardaki ilgi 7. sınıfta en yüksek iken kıyametle ilgili ortalamalar 8. sınıf öğrencilerinde en yüksek düzeyde görünmektedir. Bu durum, öğrencilerin inançla ilişkili diğer üst düzey sorunları ile ilgili konuların 8. sınıfta üst düzeye çıkması ile ilişkilidir. Bir anlamda varlığın "ne olacağız?" sorusunun cevabını aramaları ile ilişkilidir.

\section{2. İbadet Öğrenme Alanında Bulunan Konuların Sınıflara Göre Farklılaşması}

Tablo 3: İbadet Öğrenme Alanında Yer Alan Konuların Sinıflara Göre Dă̆ılımı

\begin{tabular}{|c|c|c|c|c|}
\hline & & $\mathrm{N}$ & OrT. & ss \\
\hline \multicolumn{5}{|l|}{ İslam/İslam'ın Şartları/ } \\
\hline \multirow[t]{5}{*}{ İbadet Konuları } & İlköğretim 6.sınıf & 199 & 1,5025 & 1,87723 \\
\hline & İlköğretim 7. sinıf & 191 & 1,5864 & 1,96056 \\
\hline & İlköğretim 8. sinıf & 91 & 1,1319 & 1,85118 \\
\hline & Toplam & 481 & 1,4513 & 1,90018 \\
\hline & Toplam & 481 & 0,1829 & 0,8244 \\
\hline \multicolumn{5}{|l|}{ İslam'da Helal ve } \\
\hline \multirow[t]{6}{*}{ Haramlar } & İlköğretim 6.sınıf & 199 & 0,0151 & 0,21266 \\
\hline & İlköğretim 7. sınıf & 191 & 0,0157 & 0,21707 \\
\hline & İlköğretim 8. sınıf & 91 & 0 & 0 \\
\hline & Toplam & 481 & 0,0179 & 0,23122 \\
\hline & İlköğretim 8. sınıf & 91 & 0,1099 & 0,73712 \\
\hline & Toplam & 481 & 0,0278 & 0,34459 \\
\hline \multirow[t]{4}{*}{ Namaz } & İlköğretim 6.sınıf & 199 & 1,3719 & 1,93647 \\
\hline & İlköğretim 7. sınıf & 191 & 0,1047 & 0,64034 \\
\hline & İlköğretim 8. sınıf & 91 & 0,6374 & 1,50197 \\
\hline & Toplam & 481 & 0,6978 & 1,54099 \\
\hline
\end{tabular}

Öğrencilerin ibadet öğrenme alanında yer alan beklentilerini gruplandırdığımız ilgi başlıklarından üç tanesi sınıflara göre anlamlı bir şekilde fark- 
lılaşmaktadır. Bunlardan birincisi İslam kavramının tanımı, İslam'ın temel şartları ve çeşitli ibadet konularına ilişkin olanlardır. Bu konular öğrencilerin daha çok çevresinde doğrudan gözlemlediği sorunlu konulardır. Temizlikle ilgili olanlar genellikle ergenlikle ilişkilidir. Bunun dışında oruç başta olmak üzere yeme-içme, giyinme gibi davranışla ilgili konular da bu başlık altında yer almaktadır. Bu grupta yer alan konular, öğretim programında çeşitli üniteler altında işlenmektedir. Öğrencilerin bu başlık altındaki konulara ait ortalama puanları 6 ve 7. sınıfta bir birine yakın bir düzeyde yüksek iken 8. sınıfta düşmektedir. Bu bulgu bize öğrencilerin ibadetle ilgili konularda 6 ve 7. sınıfta daha çok bilişsel öğrenmelere ilgi duyduklarını ve literal bir öğrenmeye eğilimli olduklarını göstermektedir.

İslam'da helaller ve haramlar başlığı altında öğrencilerin ilgi duyduklarını belirttiği konular birinci grupta yer alanlarla yoğun bir ilişki içindedir. Öğrenciler, bu konu altında yazdıkları konularla gündelik yaşamlarındaki davranışlarının hangilerinin İslam'a uygun olduğunu, hangilerinin ise uymadığını öğrenme arzusundadır. Bir anlamda öğretim alanının gündelik yaşamın problemlerine çözüm üretme amacı belirgin bir şekilde ortaya çıkmaktadır. Bu grup altında yer alan konulara ait ortalama puanlar da birinci grupta yer alanlar da olduğu gibi 6. ve 7. sinıfta birbirine yakın ve 8. sinıf ortalamalarından yüksektir.

Öğrencilerin ilgilendiği konuların bir kısmı "Namaz" başlığı altında toplanmıştır. Namazla ilgili olan konulara ait ortalama puanlar ise 6. sınıf öğrencilerinde 7 ve 8 . sinıf öğrencilerine göre yüksektir. 8 . sınıf öğrencilerinde ise 7. sınıf öğrencilerinden daha yüksektir. Öğretim programında namaz ünitesi 6. sınıf 2. ünitede yer almaktadır. Altıncı sınıflarda yüksek olmasında bu faktör önemlidir. Ancak 7. sınıfta ortalamanın düşerken zekat, hac ve kurban ibadetlerinin işlendiği 8. sınıfta bu ortalamanın yükselmesi anlamlıdır. Bu bulgulardan yola çıktı̆̆ımızda namaz ibadetinin 6 ve 7. sınıflarda İslam'ın temel ilkeleri çerçevesinde diğer ibadet konularıyla birlikte literal bir şekilde işlenmesinin, duyuşsal amaçlarla birlikte 8. sınıfta yeniden bağımsız bir ünite olarak yer almasının daha yararlı olacağı kanaatindeyim.

\section{Hz. Muhammed Öğrenme Alanında Bulunan Konuların Sınıflara Göre Farklılaşması}

Hz. Muhammed öğrenme alanı içinde yer alan konulara ait ortalama puanların sınıflara göre farklılaşmasını gösteren tablo 3 incelendiği zaman öğrencilerin ilgi duyduğu konular içinde Hz. Muhammed'in hayatı, öğretileri ve mucizeleri ile O'nun döneminde ve takip eden dönemlerde yaşanmış öğüt verici olaylar ve olağanüstü olayların oldukça yüksek değerlere sahip oldu- 
ğu görülecektir. Öğrencilerin bu öğrenme alanında ilgi duydukları konu gruplarından ikisi sınıflara göre anlamlı farklılaşma göstermektedir.

Bunlardan birincisi, Hz. Muhammed'in hayatı ve öğretileri başlığı altında yer alan konulara aittir. Doğumu, evlilikleri, aile yaşantısı, savaşları, insanlara neler öğrettiği gibi konulara öğrenciler daha fazla ilgi duymaktadır. Öğretim programında Hz. Muhammed'in vahiy gelene kadar olan dönemdeki hayatı 4. ve 5. sınıf konusudur. 6. sınıfta ise vefat edene kadar olan yaşantısı konu edilmektedir. Öğrencilerin ilgi duydukları konular tasnif edildiğinde böyle bir kronolojik tasnif karşımıza çıkmamaktadır. Hz. Muhammed'in hayatı ve öğretileri ile ilgili konulara ait ortalama puanlar, 6. sınıfta oldukça yüksek değerlere sahiptir ve hem 6 hem de 7. sinıflardan yüksektir. Bu ortalamalar 7. sinıfta düşmekte ve 8 . sınıfta tekrar yükselmektedir.

Hz. Muhammed öğrenme alanı ile ilgili olan ikinci konu grubu ise mucizeler, yaşanmış dini hikâyeler ve olağanüstü olaylarla ilgili olanlardan oluşmaktadır. Bunlar daha çok özellikle Hz. Muhammed'in yaşantılarındaki örnek davranış çıkarıcı nitelikteki olaylar, olağanüstü olaylar, mucizeleri ve ardından Hz. Muhammed'den sonraki dönemlerde gerçekleşen olayları merkeze almaktadır. Tablo 3'ten bu konu grubuna ait ortalama puanlar izlendiğinde 6. sınıflara ait ortalamanın, birbirine yakın değerlere sahip olan 7 ve 8. sınıflardan yüksek olarak karşımıza çıktığı gözlenmektedir.

İki konu grubuna ait değerler birlikte değerlendirildiğinde Hz. Muhammed'in hayatının kronolojik bir sunumundan ziyade olaylar ve olgular içinde nasıl yer aldığının görülmek istendiği sonucunu çıkartmaktayım. Çünkü öğrenciler, çevrelerinde kendilerine sunulandan farklı bir peygamber algısı gözlemlemektedir. Hatta bizatihi dinin kendisi yaşanan bir olgu olarak değil, insanüstü bir olgu olarak algılanmaktadır. Öğretim sürecinin bu olguyu destekleyen bir unsur olması elbette düşünülemez. Ancak, Hz. Muhammed'in hayatı anlatılırken, yaşamının çeşitli kesitlerine girilerek olaylar içinde yaşayan ve dinin temel ilkeleri çerçevesinde tepki veren bir insan olarak anlatılmalıdır. Hz. Muhammed, olayların içinde olmalıdır diye düşünüyorum. Tarihsel süreç içine girildiğinde hem öğreneni konudan uzaklaştırmakta hem de yaşamın içindeki yanlış algılar düzeltilememektedir. Öğretimin, mucize, keramet ve diğer doğaüstü olayları hiç yokmuş gibi davranması düşünülemez. Öğretim sürecinde bu konuların da içeriğe dahil edilmesi, ancak doğru davranış kazandırması amaçlanmalıdır. Öğrencilerin çevrelerindeki yanlış anlama ve algıları öğretim süreci içine taşıması teşvik edilmelidir. Öğrencilerden alınan bilgilerde bu konuların ilgi çektiğinin görülmesi aynı zamanda öğretmenlerin kullandığı içerik ve yöntemlerle de ilgilidir. Öğretmenlere de bu konularda hizmet içi eğitim vasıtasıyla doğru anlayış kazandırılmalıdır. 
Tablo 4: Hz. Muhammed Öğrenme Alanında Yer Alan Konuların Sınıflara Göre Dağglımı

\begin{tabular}{llrcc} 
& & N & Ort. & ss \\
\hline Hz. Muhammed'in & & & & \\
Hayatı ve Öğretileri & 6.sinıf & 199 & 3,0754 & 2,10803 \\
& 7. sinıf & 191 & 1,2199 & 1,94499 \\
& 8. sinıf & 91 & 2,6593 & 2,21219 \\
& Toplam & 481 & 2,3181 & 2,22406 \\
& Toplam & 481 & 0,0258 & 0,25508 \\
Mucize/Olağanüstü & & & & \\
Olaylar/ Keramet/ & & & & \\
Yaşanmış Dini Hikayeler & 6.sınıf & 199 & 0,3467 & 1,18721 \\
& 7. sinıf & 191 & 0,1257 & 0,61123 \\
& 8. sinıf & 91 & 0,1538 & 0,84226 \\
& Toplam & 481 & 0,2127 & 0,91495 \\
\hline
\end{tabular}

\section{Kur'an ve Yorumu Öğrenme Alanında Bulunan Konuların Sınıflara} Göre Farklılaşması

Öğrencilerin ilgilendikleri konulardan "Kur'an ve Yorumu" öğrenme alanında bulunanlardan ortalaması sınıflara göre anlamlı bir şekilde farklılaşan sadece "Kur'an-1 Kerim-öğretileri ve öğretimi"dir. Bu başlık altında verilen konulara ait ortalama puanların sınıflara göre dağılımı tablo 5 'te verilmektedir. Bu tablo incelendiği zaman 7. sınıflardaki ortalamanın birbirine yakın değerlere sahip 6 ve 8. sınıf ortalamasından yüksek olduğu görülmektedir. Öğretim programında 7. sınıfta bu alanda "Kur'an'da Akıl ve Bilgi" isimli ünite yer almaktadır. Öğrencilerin ilgilendikleri konuların çözümünde Kur'an'ın Arapça okunmasının öğrenilmesi, anlamının ve Kur'an'ın insanlara sunduğu yaşam tarzı ile beklentiler gözlenmektedir. Yedinci sınıftaki ünite içeriği ile öğrenci ilgileri örtüşmemektedir. Kur'an'ın Arapça okutulması ilköğretim sürecinde elbette mümkün bir talep olmayabilir. Ancak anlamının okutulması belli temel kavramları merkeze alarak yıllara dağıtılması gerekir. Özellikle 5. sınıfta bulunan kıssaların her bir yılda ikişer veya üçer olarak çoğaltılmak suretiyle verilmesi mümkün olabilir.

Tablo 5: Kur'an ve Yorumu Öğrenme Alanında Yer Alan Konuların Sınıflara Göre Dağılımı

\begin{tabular}{llrrr} 
& & N & Ort. & ss \\
\hline Kuran-1 Kerim/Öğretileri/ & & & & \\
Öğretimi & 6.sinıf & 199 & 0,3216 & 1,02843 \\
& 7. sinıf & 191 & 0,8115 & 1,60462 \\
& 8. sinıf & 91 & 0,2637 & 1,02019 \\
& Toplam & 481 & 0,493 & 1,29027 \\
\hline
\end{tabular}




\section{Ahlak Öğrenme Alanında Bulunan Konuların Sınıflara Göre Farklılaşması}

Tablo 6: Ahlak Öğrenme Alanında Yer Alan Konuların Sınıflara Göre Dağılımı

\begin{tabular}{llrrr} 
& & N & Ort. & ss \\
\hline Ahlak/İslam Ahlakl/ & & & & \\
Ahlaki Görevlerimiz & 6.sinıf & 199 & 1,6734 & 1,75489 \\
& 7. sinıf & 191 & 0,2461 & 0,93874 \\
& 8. sinıf & 91 & 0,6813 & 1,45967 \\
& Toplam & 481 & 0,9324 & 1,57147 \\
& & & & \\
Aile/Anne/Baba Hakları & 6.sinıf & 199 & 0,1357 & 0,6939 \\
& 7. sinıf & 191 & 0,3613 & 1,16545 \\
& 8. sinif & 91 & 0 & 0 \\
& Toplam & 481 & 0,1909 & 0,85115 \\
\hline
\end{tabular}

Öğrencilerin ilgi duydukları konulardan ahlak öğrenme alanında yer alanlardan sınıflara göre anlamlı farklılaşma gösteren iki grup karşımıza çıktı. Bunlardan birincisi genel anlamda kavramı, İslam'ın ahlak anlayışı ve ahlaki görevlerimiz başlıkları altında toplanmaktadır. Bu konulara ait ortalama puanlar 6. sınıfta en yüksek düzeyde iken, 7. sınıfta oldukça düşmekte ve 8 . Sinıfta tekrar bir miktar yükselmektedir. İkinci konu grubu aile içi ilişkiler, anne ve baba hakları başlığını taşımakladır. Bu konu grubuna ait ortalamalar 7. sınıfta 5. ve 8. sınıftan daha yüksektir. 8. sınıfta bu grup altında ilgi duyulan hiçbir konu bulunmamaktadır.

Öğretim programında ahlak öğrenme alanında 6. sınıfta İslam'ın Sak1nılmasını İstediği Davranışlar, 7. sınıfta İslam Dinine Göre Kötü Alışkanlıklar ve 8. sınıfta Din ve Güzel Ahlak başlıklarını taşımaktadır. Öğrencilerden elde edilen bulgular çerçevesinde ahlaki konuların ögüt/nasihat tarzı bir yapılanmaya sıcak bakmadıkları anlaşılmaktadır. Özellikle 8. sınıftan sonra ahlakla ilgili konulara ilginin tamamen ortadan kalktı̆̆ 1 gözlenmektedir. Bu sebeple ahlak öğrenme alanının 6. sınıftan sonra öğretim programlarında bulunmaması, bunun yerine Kur'an ve Hz. Muhammed öğrenme alanlarındaki ünitelerle bu boşluğun doldurulması gerektiği düşüncesindeyim. Altıncı sınıfa kadar olan konularda ise yasakçı bir anlama biçiminden ziyade olumlu davranışları teşvik edici bir yöntemin izlenmesi taraftarıyım. Çünkü öğrencilerde teşvik edilen olumlu davranışlarla ilgili öğrenmelere açık oldukları halde yasaklanan davranışların ard arda sıralandığı konulara ilgi duymadıkları gözlenmektedir. 


\section{Din ve Kültür Alanında Bulunan Konuların Sınıflara Göre Farklılaşması}

Öğrencilerin din ve kültür alanında yer alan ilgi duydukları konu gruplarına ait ortalama puanların sinıflara göre farklılaşması tablo 7'de verilmektedir. Tablo incelendiği zaman bu öğrenme alanında yer alabileceği düşünülen yedi konu gurubunun sınıflara göre anlamlı bir şekilde farklılaştığı gözlenmektedir.

Bunlardan ilki diğer dinler ve özellikleri hakkında bilgi vermeyi amaçlayan konulardır. İslam dini dışında kalan özellikle Hıristiyanlık, Yahudilik ve Uzakdoğu dinlerinin inançları, ibadet ve ritüelleri gibi gözlenebilir nitelikteki konular ilgi duyulan boyutlar olarak karşımıza çıkmaktadır. Bu konulara ait ortalama puanlar, 6. sınıfta sıfır iken, 7. sınıfta yükselmekte ve 8. sınıfta düşmektedir.

Benzer bir durum Hz. Muhammed dışındaki peygamberin hayatları ve öğretileri ile ilgili konulara ait ortalamalarda karşımıza çıkmaktadır. Bu konu grubu ortalamaları, 6. sınıfta oldukça düşük iken 7. ve 8. sınıflarda yükselmektedir. En yüksek ortalama 8. sınıfta gözlenmektedir.

İslam dini dışındaki dinlere ait kutsal kitaplarla ilgili konuların ortalaması ise bunların tam zıddıdır. Altıncı sınıflarda oldukça yüksek bir ortalama iken, 7 ve 8. sınıflarda giderek düşmektedir. Bu durumun ortaya çıkmasında mevcut programda 6. sınıf üniteleri içinde peygamberlere ve ilahi kitaplara inanç konusunun bulunması etkilidir. Bu ünitenin öğretimi, öğrencilerde kutsal kitaplar hakkında daha ayrıntılı bilgi edinme ilgisi ortaya çıkarmış olabilir. Ancak bu durum 7. sınıfta diğer dinlerle ilgili konulara ait yüksek ortalamayı açıklamamaktadır. Çünkü 7. sınıflarda inanç alanında melek ve ahiret inancının öğretimi yapılırken din ve kültür öğrenme alanında ise kültürümüz ve din konusu öğretilmektedir. Diğer dinlerle ilgili konulara 7. s1nıfta ortaya çıkan bu yüksek ilginin sebepleri, bağımsız araştırmalarla açıklanmaya muhtaçtır.

Din kurumu, ihtiyaç olma durumunun tartışılması ve dinin özellikleri gibi çok teorik konulara ilgi duyan öğrenciler de bulunmaktadır. Bu başlık altında topladığımız konulara ait ortalama puanlar 6. sınıflarda en düşük düzeyde iken 7 ve 8 . sinıflarda giderek yükselmektedir. Dinin toplumsal boyutu, devletle ilişkileri ve laiklikle ilgili konulara ait ortalamalardaki farkl1laşma için de benzer bir durum söz konusudur. Bu grupta yer alan ortalama puanlar düşük bir ortalama ile 6. sınıflarda karşımıza çıkarken, 7. sınıflarda sıfır ortalama, 8. sınıflarda ise her iki sınıftan daha yüksek bir ortalama 
gerçekleşmektedir. Ancak bu grup içinde yer alan konulara ait ortalamalar diğer konulara göre oldukça düşük düzeydedir.

Öğrencilerin ilgi duydukları konular arasında bir diğeri ise İslam Tarihi, Coğrafyası, Kültür ve Uygarlığı başlığı altında toplanmaktadır. Bu grupta yer alan konulara ait ortalama puanlar, 6 . sinıflarda en yüksek düzeyde iken 7 ve 8. sınıflarda birbirine yakın oranda ve düşük düzeydedir. 6. sınıf Din ve Kültür öğrenme alanında "İslamiyet ve Türkler" ünitesi yer almaktadır. Bu ünitenin öğretimi Türklerin İslam'la tanışmalarından sonra ürettikleri uygarlık ile Hz. Muhammed'in ölümünden sonraki ara dönemde kalan süreç hakkında öğrencilerde bir ilgi uyandırmaktadır. İlköğretim programları hiçbir şekilde Hz. Muhammed'in ölümünden Türklerin İslam'ı kabulü arasındaki dönemi inceleme konusu yapmamaktadır. Bu durum, öğrencilerin Türklerin medeniyet oluştururken aldıkları mirası anlamlandırmasında ve 8. sınıf "İslam Düşüncesinde Yorumlar" ünitesinin öğretiminde sorunlar oluşturmaktadır. Uygarlık üretimindeki bu süreklilik arz eden çizginin öğretim programları tarafından öğrenciye fark ettirilmesi gerekmektedir. Bu aynı zamanda günümüzdeki durumun yorumlanması açısından da gereklidir. Artık kuramsal tartışmalar yapmaya başlayan öğrencilerin İslam uygarlığının bugününü de değerlendirebilmesi gereklidir.

Din ve Kültür öğrenme alanı ile ilgili bir diğer ilgi boyutu ise sihir ve büyü konularıdır. Öğrencilerin düşük de olsa 6. sınıfta toplumda duydukları ve işittikleri konular olarak bu konulara ilgi duydukları gözlenmektedir. Bu ilgi, 7. sınıfta yükselmekte ve 8. sınıfta 6. sınıf düzeyinin de altına inmektedir. Bu durum, öğrencilerin çevreden edindikleri bazı yanlış bilgilerinin ve duyumlarının düzeltilmesi için 6 ve 7. sınıflarda -örneğin Kültürümüz ve Din- ünitesi içinde öğretime konu edilmesi gerektiğini göstermektedir.

Tablo 7: Din ve Kültür Öğrenme Alanında Yer Alan Konuların Sınıflara Göre Dağılımı

\begin{tabular}{llrrr} 
& & N & Ort. & ss \\
\hline Diğer Dinler ve Özellikleri & & & & \\
Hakkında Bilgi & 6.sinıf & 199 & 0 & 0 \\
& 7. sinıf & 191 & 0,199 & 0,8536 \\
& 8. sinıf & 91 & 0,0549 & 0,43109 \\
& Toplam & 481 & 0,0855 & 0,56336
\end{tabular}


Diğer Peygamberlerin

Hayatları ve Öğretileri

$\begin{array}{lrrr}\text { 6.sinif } & 199 & 0,3216 & 1,0527 \\ \text { 7. sinif } & 191 & 0,4974 & 1,23916 \\ \text { 8. sinif } & 91 & 0,5275 & 1,23235 \\ \text { Toplam } & 481 & 0,5328 & 1,3339\end{array}$

Din Kurumu/ İhtiyaç olma durumu ve Özellikleri

$\begin{array}{lrrr}\text { 6.sinif } & 199 & 0,1809 & 0,80869 \\ \text { 7. sinif } & 191 & 0,5131 & 1,28087 \\ \text { 8. sinif } & 91 & 1,2088 & 1,81056 \\ \text { 5. Sinif } & 22 & 0,1818 & 0,8528 \\ \text { Toplam } & 481 & 0,493 & 1,27786\end{array}$

İslam Tarihi/Coğrafyası/ Kültür ve Uygarlığı

$\begin{array}{lrrr}\text { 6.sinif } & 199 & 0,2513 & 0,95726 \\ \text { 7. sinif } & 191 & 0,0262 & 0,36179 \\ \text { 8. sinif } & 91 & 0,022 & 0,20966 \\ \text { Toplam } & 481 & 0,1193 & 0,66925\end{array}$

Dinin Toplumsal Boyutu/ Devletle İlişkileri/Laiklik

$\begin{array}{lrrr}\text { 6.sinif } & 199 & 0,0251 & 0,25499 \\ \text { 7. sinif } & 191 & 0 & 0 \\ \text { 8. sinif } & 91 & 0,0549 & 0,34521 \\ \text { Toplam } & 481 & 0,0258 & 0,25508 \\ & & & \\ \text { 6.sinif } & 199 & 1,9296 & 2,02387 \\ \text { 7. sinif } & 191 & 0,3141 & 1,01865 \\ \text { 8. sinif } & 91 & 0,1538 & 0,64847 \\ \text { Toplam } & 481 & 0,9105 & 1,66459 \\ & & & \\ \text { 6.sinif } & 199 & 0,2261 & 0,90125 \\ \text { 7. sinif } & 191 & 0,3089 & 1,05325 \\ \text { 8. sinif } & 91 & 0,1429 & 0,79682 \\ \text { Toplam } & 481 & 0,2684 & 0,99076\end{array}$

\section{SONUÇ VE ÖNERILER}

İlköğretim din kültürü ve ahlak bilgisi dersini almakta olan 6-7 ve 8. sınıf öğrencilerinden elde ettiğimiz bulgular çerçevesinde aşağıdaki sonuçlara ulaşılmış ve bu sonuçlar çerçevesinde öneriler geliştirilmiştir: 


\section{1. İnanç Öğrenme Alanı ile illgili Olanlar:}

\begin{tabular}{|c|c|c|c|}
\hline & 6. Sinif & 7. Sinif & 8. Sinif \\
\hline $\begin{array}{l}\text { Mevcut } \\
\text { Program }\end{array}$ & $\begin{array}{l}\text { Peygamberlere ve } \\
\text { İlahi Kitaplara İnanç }\end{array}$ & Melek ve Ahiret İnancı & Kaza ve Kader \\
\hline $\begin{array}{l}\text { Öğrenci } \\
\text { İlgileri }\end{array}$ & & $\begin{array}{l}\text { Allah düşüncesi- } \\
\text { Allaha İman-Ahiret- } \\
\text { Ölümden Sonraki } \\
\text { Hayat-Evren ve } \\
\text { Dünyanın Yaratılış1- } \\
\text { Melekler ve Melek- } \\
\text { lere İman-Diğer } \\
\text { Görünmeyen Varlıklar }\end{array}$ & $\begin{array}{l}\text { İmanla ilgili üst } \\
\text { düzey konular-Kaza } \\
\text { ve Kader- Kiyamet ve } \\
\text { Alametleri }\end{array}$ \\
\hline
\end{tabular}

Öneriler 4 ve 5. sınıflar araştırma kapsamına alınmamakla birlikte elde edilen bulgulara göre inançla ilgili konulara 7. sınıftan itibaren başlanmasının daha uygun olacağı düşünülmektedir. Bu sınıfa kadar inancın sadece somut yansımaları üzerinde durulmalıdır. Öğretmenlerin bu konuların işlenmesinde kullandığ yöntem, teknik ve öğretim araçları da etken bir faktör olmakla birlikte öğrencilerin inançla ilgili konularla yoğun bir şekilde 7. sınıfta ilgilenmeye başladığı ve 8 . sınıftan itibaren daha üst düzey analiz ve düşünme becerileri kullanmayı gerektiren konulara ilgi yönelttiği anlaşılmaktadır.

\section{2. İbadet Öğrenme Alanı ile Illgili Olanlar}

\begin{tabular}{|c|c|c|c|}
\hline & 6. Sinif & 7. Sinif & 8. Sinif \\
\hline $\begin{array}{l}\text { Mevcut } \\
\text { Program }\end{array}$ & Namaz İbadeti & $\begin{array}{l}\text { Ramazan Ayı ve Oruç } \\
\text { İbadeti }\end{array}$ & $\begin{array}{l}\text { Zekat, Hac ve Kurban } \\
\text { İbadeti }\end{array}$ \\
\hline $\begin{array}{l}\text { Öğrenci } \\
\text { İlgileri }\end{array}$ & $\begin{array}{l}\text { İslam Kavramı, } \\
\text { İslam'ın Şartları, } \\
\text { Gündelik Hayatta } \\
\text { Karşılaşılan İbadet } \\
\text { Konuları, Helaller- } \\
\text { Haramlar, Namaz } \\
\text { İbadeti }\end{array}$ & $\begin{array}{l}\text { İslam Kavramı, } \\
\text { İslam'ın Şartları, } \\
\text { Gündelik Hayatta } \\
\text { Karşılaşılan İbadet } \\
\text { Konuları, Helaller, } \\
\text { Haramlar }\end{array}$ & Namaz İbadeti \\
\hline Öneriler & \multicolumn{3}{|c|}{$\begin{array}{l}\text { Öğrencilerin 6. ve 7. sınıflarda ibadetle ilgili literal öğrenmeye eğilimleri } \\
\text { vardır. Etraflarında gözlemledikleri, yaşamlarını doğrudan ilgilendiren } \\
\text { yeme, içme, giyinme, ergenlik dönemi ile ilişkili temizlik konuları vb. } \\
\text { hususlarda yapıp etmelerinin dindeki yerini öğrenme ihtiyacı içindedirler. } \\
\text { Namaz ibadeti 6. sınıfta teorik çerçevede İslam'ın temel ibadetleri içindeki } \\
\text { yerini vurgulayarak işlenmeli ama } 8 \text {. sınıfta duyuşsal hedefleri merkeze } \\
\text { alarak bağımsız bir ünite olarak yer almalıdır. }\end{array}$} \\
\hline
\end{tabular}


3. Hz. Muhammed Öğrenme Alanı ile Illgili Olanlar

\begin{tabular}{|c|c|c|c|}
\hline & 6. Sinif & 7. Sinif & 8. Sinif \\
\hline $\begin{array}{l}\text { Mevcut } \\
\text { Program }\end{array}$ & $\begin{array}{l}\text { Son Peygamber Hz. } \\
\text { Muhammed (Vahyin } \\
\text { gelişinden vefatına } \\
\text { kadar) }\end{array}$ & $\begin{array}{l}\text { Bir İnsan ve } \\
\text { Peygamber Olarak } \\
\text { Hz. Muhammed }\end{array}$ & $\begin{array}{l}\text { Hz. Muhammed'in } \\
\text { Hayatından Örnek } \\
\text { Davranışlar }\end{array}$ \\
\hline $\begin{array}{l}\text { Öğrenci } \\
\text { İlgileri }\end{array}$ & $\begin{array}{l}\text { Hz. Muhammed'in Ha- } \\
\text { yatı ve Öğretileri, Mu- } \\
\text { cize, keramet, Olağan- } \\
\text { üstü olaylar, yaşanmış } \\
\text { dini hikayeler }\end{array}$ & & $\begin{array}{l}\text { Hz. Muhammed'in } \\
\text { Hayatı ve Öğretileri }\end{array}$ \\
\hline Öneriler & \multicolumn{3}{|c|}{$\begin{array}{l}\text { Öğrencilerin Hz. Muhammed'in hayatını kronolojik olarak tarihi bir şahsiyet } \\
\text { olarak öğrenmeye eğilimi gözlenmemektedir. Onların ilgileri, daha çok } \\
\text { O’nun yaşantısından çıarılan çoğunlukla doğaüstü olaylara yöneliktir. Bu } \\
\text { ilgi göz önünde bulundurularak Hz. Muhammed öğrenme alanındaki } \\
\text { öğretim, ilk sınıflarda O'nun hayatından çıkarılan davranış oluşturmaya } \\
\text { yönelik somut olaylara odaklanmalıdır. Bir ünitenin birden fazla davranışa } \\
\text { yönelip, ard arda ahlaki davranışları sıralaması da insanüstü bir tipleme } \\
\text { oluşturulmasına sebep olabilmektedir. Bunun yerine onun bir insan olarak } \\
\text { davranışlarını, tepkilerini, duygularını ortaya koyan olaylar merkeze } \\
\text { alınarak davranış oluşturmaya gidilmelidir. }\end{array}$} \\
\hline
\end{tabular}

\section{Kur'an ve Yorumu Öğrenme Alanı ile Illgili Olanlar}

\begin{tabular}{|c|c|c|c|}
\hline & 6. Sinif & 7. Sinif & 8. Sinif \\
\hline Mevcut & Kur'an'in Temel & Kur'an'da Akıl ve & İslam Düşüncesinde \\
\hline Program & Eğitici Nitelikleri & Bilgi & Yorumlar \\
\hline $\begin{array}{l}\text { Öğrenci } \\
\text { İlgileri }\end{array}$ & & $\begin{array}{l}\text { Kur'an/Öğgretileri } \\
\text { Öğretimi }\end{array}$ & \\
\hline
\end{tabular}

Öneriler Öğrenciler, genel hatlarıyla Kur'an'ı tanımak, Arapçasından okuyabilmek ve anlamını okumak istemektedir. Arapçasından okunmasını öğretmek, ilköğretim Din Kültürü ve Ahlak Bilgisi dersleri amaçları arasında yer alamaz. Bu görev caminin görevidir ve öğretim süreci cami ile ilişkiyi ve bu konudaki yönlendirmeyi yapmak durumundadır. Ancak anlamının okutulması özellikle temel kavramlar ve kıssaları kullanarak gerçekleştirilebilir. Kur'an'da akıl ve bilgi ünitesi bu çerçevede işlevsel değildir. Daha çok kavramın daha öz biçimde bu öğretim alanında yer alması gerekir. İslam Düşüncesinde Yorumlar ünitesi ise bu öğrenme alanı ile doğrudan ilişkili olmadığı gibi öğretim sürecinde öğretmenlerin en fazla zorlandığ ünitelerde bu ünitenin amaçlarını destekleyici ön öğrenmeler bulunmamaktadır. Ayrıca bu ünite diğer derslerle yoğun bir işbirliğini gerektirirken konuları itibarıyla ilköğretim derslerinde bu üniteyi destekleyici içerik bulunmamaktadır. Bu ünitenin tamamıyla çıkarılm 


\section{Ahlak Öğrenme Alanı ile Illgili Olanlar}

\begin{tabular}{llll}
\hline & 6. Sınıf & 7. Sınıf & 8. Sınıf \\
\hline $\begin{array}{l}\text { Mevcut } \\
\text { Program }\end{array}$ & $\begin{array}{l}\text { İslam'ın } \\
\text { Sakınılmasını İstediği } \\
\text { Davranışlar }\end{array}$ & $\begin{array}{l}\text { İslam Dinine Göre } \\
\text { Kötü Davranışlar }\end{array}$ & Din ve Güzel Ahlak \\
& & & \\
\hline $\begin{array}{l}\text { Öğrenci } \\
\text { İlgileri }\end{array}$ & $\begin{array}{l}\text { Ahlak kavramı. İslam } \\
\text { ahlakı, ahlaki } \\
\text { görevlerimiz }\end{array}$ & $\begin{array}{l}\text { Aile, anne-baba } \\
\text { hakları. }\end{array}$ \\
& $\begin{array}{l}\text { Öğrenciler, birbiri ardına öğütler içeren nasihat türü bir ahlak öğretimini } \\
\text { benimsememektedir. Özellikle İslam'ın sakınılmasını istediği davranışlar }\end{array}$ \\
& $\begin{array}{l}\text { ve İslam dinine göre kötü davranışlar ünitesi bu çerçevede } \\
\text { değerlendirilmektedir. Ahlak öğrenme alanı 8. sinıfta bulunmamalıdır. } \\
\text { Bunun yerine ahlaki konular, Hz. Muhammed ve Kur'an öğrenme alanı } \\
\text { içinde dağıtılmalıdır. }\end{array}$ \\
\hline
\end{tabular}

\section{Din ve Kültür Öğrenme Alanı ile Illgili Olanlar}

\begin{tabular}{|c|c|c|c|}
\hline & 6. Sinif & 7. Sinif & 8. Sinif \\
\hline $\begin{array}{l}\text { Mevcut } \\
\text { Program }\end{array}$ & İslamiyet ve Türkler & Kültürümüz ve Din & $\begin{array}{l}\text { Dinler ve Evrensel } \\
\text { Öğütleri }\end{array}$ \\
\hline $\begin{array}{l}\text { Öğrenci } \\
\text { İlgileri }\end{array}$ & $\begin{array}{l}\text { İslam tarihi. Coğraf- } \\
\text { yası ve uygarlığı, } \\
\text { Diğger dinlere ait } \\
\text { kutsal kitaplar, }\end{array}$ & $\begin{array}{l}\text { Diğer dinler ve } \\
\text { özellikleri, sihir ve } \\
\text { büyü gibi toplumdaki } \\
\text { dinle ilişkili uygula- } \\
\text { ma ve inançlar }\end{array}$ & $\begin{array}{l}\text { Diğer peygamberin } \\
\text { hayatları ve } \\
\text { ögretileri, dinin } \\
\text { toplumsal boyutu, } \\
\text { devletle ilişkileri, } \\
\text { laiklik, }\end{array}$ \\
\hline
\end{tabular}

Öneriler Diğer dinlerin öğretimi inanç öğrenme alanında 6. sınıftan itibaren kutsal kitaplar ve peygamberler üniteleri içinde karşılaştırmalı ve dinlerin kendi kaynaklarına dayalı olarak verilmeli, 8. sınıfta ise genel anlamda din kavramı altında kurumsal temelde işlenmelidir. Öğrenciler 8. sınıfta daha çok teorik tartışmalara girmeye eğilimli görünmektedir. Bu sınıfta dinlerin kurumsal yapıları, inanç ve öğretileri, ritüelleriyle birlikte verilmelidir. 6 ve 7. sinıflar, kutsal kitap ve peygamber kavramı altında ortak değerlere odaklanmalıdır. 8. sınıfta öğrenci kendi dininin farklılıklarını görebilmelidir. $\mathrm{Bu}$ öğrenme alanı, Hz. Muhammed'in vefatından sonraki süreci, Türklerin İslam'la tanışmalarına kadar kültür ve uygarlık oluşumunu izleyebilecek şekilde tanıtmalıdır. 